\title{
The Accumulated Earnings Tax
}

The accumulated earnings tax ${ }^{1}$ is a penalty tax designed to discourage the use of a corporate "umbrella" for personal income. The "umbrella" principle is simple: since corporation taves are lower than high-bracket personal taxes, wealthy taxpayers would benefit if they could incorporate their businesses, extract sufficient salaries and dividends to meet their living expenses, and leave the surplus income from the business as undistributed corporate profits.

Two statutory obstacles limit resort to this umbrella. First, unless corporate income arises chiefly from the active conduct of a trade or business, the corporation may be declared a personal holding company and its undistributed income subjected to a penalty tax.' Second, a penalty tax, known as the accumulated earnings tax, applies if the corporation is "formed or availed of for the purpose of avoiding the [personal] income tax...."3 Since an intent to avoid taxes may be hard to divine, the Code adopts a rebuttable presumption that the accumulation of earnings "beyond the reasonable needs of the business" betrays the prohibited purpose. ${ }^{4}$ In practice, the presumption is virtually con-

1. INT. REv. CODE OF 1954, $\$ 531$ [hereinafter cited as IRC] provides:

In addition to other taxes imposed by this chapter, there is hereby imposed for cach taxable year on the accumulated taxable income (as defined in section 535) of crery corporation described in section 532, an accumulated carnings tax equal to the sum of-

(1) $271 / 2$ percent of the accumulated taxable income not in excess of $\$ 100,000$, plus

(2) $381 / 2$ percent of the accumulated taxable income in excess of $\$ 100,000$.

2. IRC $\$ \$ 541-47$.

3. The general scheme of taxation under the accumulated carnings tax is to impose the $\operatorname{tax}$ on

[e]very corporation . . . formed or availed of for the purpose of avoiding the income tax with respect to its shareholders or the shareholders of any other corporation, by permitting earnings and profits to accumulate instead of being divided or distributed.

IRC $\S 532$.

4. IRC \& 533 provides:

(a) ... For purposes of section 532, the fact that the earnings and profits of a corporation are permitted to accumulate beyond the reasonable needs of the business shall be determinative of the purpose to avoid the income tax with respect to sharcholders, unless the corporation by the preponderance of the evidence shall prove to the contrary.

"Reasonable needs of the business" receives further definition in section 537 which provides "For purposes of this part, the term 'reasonable needs of the business' includes the reasonably anticipated needs of the business." Section 534 provides that in Tax Court proceedings, a corporation may shift the burden of proof of an improper accumulation to the government by submitting a statement of the grounds upon which it intends to rely in resisting the government's contention, together with facts supporting its position. Section 535 sets forth the method of computing accumulated taxable income, which basically consists of making certain adjustments to a corporation's net taxable income for the year in which there was an alleged improper accumulation, and then deducting dividends paid and earnings retained for the reasonable needs of the business. 
clusive-a finding of an unreasonable accumulation generally leads to a finding of a tax avoidance purpose.

Imposition of the accumulated earnings tax, then, depends on an estimation of what are "reasonable business needs." These needs basically are twofold: requirements for a business' current operations and future needs. ${ }^{5}$ While future needs depend on the size and direction of expansion, which is usually difficult to foresee, current needs can be estimated with far greater accuracy. Thus, a court need not be dependent on the businessman (or the IRS) for an estimate of reasonable working capital needs, but can cross-check using available accounting techniques. On the other hand in measuring accumulations justified by expansion plans the court can only ask for evidence of the seriousness and specificity of those plans.

Accounting techniques, however, have rarely been used to measure current needs. Instead, one or another rule of thumb has found favor. Some courts compare a firm's current assets-to-current liabilities ratio with that of other firms, or of other years for the same firm. ${ }^{\circ}$ Other courts create a presumption of reasonableness if working capital does not exceed one year's operating expenses, exclusive of cost of goods sold. $^{7}$ Neither of these guidelines is satisfactory. This comment will

5. Contingencies such as a downturn in profits or prolonged litigations may also create reasonable needs for accumulation of working capital.

6. J. Gordon Turnbull, Inc. v. Comm'r, 41 T.C. 358 (1963), illustrates the use of two of these ratios. Cases using ratios of prior year or years to the year in dispute include: I. A. Dress Co. v. Comm'r, 32 T.C. 93 (1959), aff'd, 273 F.2d 543 (2d Cir. 1960), cert. denied, 362 U.S. 976 (1960); R. C. Tway Co. v. Gray, 5 AFTR 2d 849 (TV.D. Ky. 1956), Barrow Mfg. Co. v. Comm'r, 294 F.2d 79 (5th Cir.), cert. denied, 369 U.S. 817 (1961); Wellman Operating Corp. v. Comm'r, 33 T.C. 162 (1959); United Block Co. v. Helvering, 9 P.H TAX CT. REP. \& MEM. DEc. 932 (1940), aff'd, 123 F.2d 704 (2d Cir. 1941), ccrt. denied, 315 U.S. 812 (1942). Cases comparing ratios of taxpayer to those of his competitors include: Motor Fuel Carriers, Inc. v. United States, 322 F.2d 576 (5th Cir. 1963); Stcrling Distributors, Inc. v. United States, 313 F.2d 803 (5th Cir. 1963).

7. The origin of this presumption seems to be J. L. Goodman Furniture Co. v. Comm'r, 11 T.C. 530 (1948). It has been followed in Hedberg-Friedheim Contracting Co. 25 P-H TAX CT. REP. \& MEM. DEC. 1171 (1956), aff'd, 251 F.2d 839 (8th Cir. 1958); and F. E. Watkins Motor Co. v. Comm'r, 31 T.C. 288 (1958). Generally, however, courts have qualified or implicitly rejected this presumption, terming it a rule of administrative convenience to be applied in the context of the particular fact situation. Dixic, Inc. v. Comm'r, 277 F.2d 526 (2d Cir.), cert. denied, 364 U.S. 827 (1960); Barrow Mfg. Co. v. Comm'r, 294 F.2d 79 (5th Cir.), cert. denied, 369 U.S. 817 (1961). Sterling Distributors, Inc. v. United States, 313 F.2d 803 (5th Cir. 1963) (presumption given some weight but only on facts of case); Motor Fuel Carriers, Inc. v. United States, 322 F.2d 576 (5th Cir. 1963) (presumption not a "controlling principle"); Robert $\mathrm{R}$. Walker, Inc. 34 P.H TAx CT. REP. \& MEM. DEc. 154 (1965); Apollo Industries, Inc. v. Comm'r, 44 T.C. 1 (1965) (on appeal, lst Cir. Aug. 18, 1965); Shaw-Walker Co., 34 P-H TAx CT. REP. \& MEM. DEc. 1872 (1965). Courts instead prefer broad criteria for measuring working capital needs. The criteria most often cited are "the nature of the business, its credit policies, the amounts of inventories and rate of turnover, the amount of accounts receivable and the collection rate thereof, the availability of credit to the business, and similar relevant factors," Smoot Sand \& Gravel Corp. v. Comm'r, 241 F.2d 197, 207 (4th Cir.), cert. denied, 354 U.S. $922(1957)$. Recently there is some evidence that courts have rejected this presumption 
attempt to develop out of the "operating cycle" method suggested in several recent cases a systematic and reliable approach for estimating "reasonableness."

Working capital represents the cash needed by a corporation to conduct its day-to-day operations. Working capital needs arise because a corporation incurs expenses in connection with the manufacture and sale of its products before it receives payment for them. ${ }^{8}$ An example may clarify the difference between working capital needs and other operating costs that do not relate to cash requirements. In the usual manufacturing process there is a delay between receipt of the order and payment for the goods, during which time costs accrue. Some of these costs are direct costs-arising wholly or largely from the production of the particular product. The raw materials used and the wages paid to the men on the production line are examples of direct costs. Other costs are indirect and represent an attempt to allocate to each unit produced a part of the costs of running the enterprise as a whole. These indirect costs include factory and equipment depreciation, and the salaries of executive, sales and bookkeeping personnel. But costs, whether direct or indirect, do not create a need for working capital except to the extent that they become expenses before payment is received for the goods produced. Thus, the corporation probably must pay its production workers before it receives payment for their product. Similarly, it may have to replenish inventory and pay salaries of office personnel. Other costs, such as depreciation, however, may not create a need for cash-in order to replace equipment-until long after payment is received. Working capital must meet only those operating expenses which will be incurred after production has begun but before payment has been received.

To meet its operating expenses a corporation must either have adequate cash on hand, or borrow the amount needed, or defer payment of its obligations. Which of these three alternatives a corporation chooses to follow is a matter of managerial discretion. Under Treas. Regs. $\S 1.537-1$ (a) (1965) this discretion is not subject to attack by the government as unreasonable unless the amount of working capital set aside to meet expenses is greater than " $[t]$ he amount that a prudent

outright, United States v. MrNally Pittsburg Mfg. Corp., 342 F.2d 198 (10th Cir. 1965), but cf. John P. Scripps Newspapers v. Comm'r, 44 T.C. 453 (1965) and Churchill Construc: tion Co. v. United States, 17 Am. Fed. Tax. R.2d 045 (N.D. Ohio 1965) (presumption cited as an acceptable guideline in charge to the jury).

8. As used in this comment, "expenses" means those costs which must be met before payment is received for the products in question. 
businessman would consider appropriate." Thus a corporation may retain working capital which will provide adequate cash to meet expenses incurred during production and other expenses necessary to operation.

\section{Expenses Incurred During Production I: General and Administra- tive Expenses}

These are indirect expenses incurred after commencement of pro. duction and before a sale or delivery of an order. The sale or delivery point is the point at which title passes to the purchaser or the buyer assumes the risk of loss, which should be the time when the seller enters the sale on his books or creates an account receivable. Wages, rent, fuel, insurance, and replacement of supplies and materials used up in production are typical costs which an enterprise incurs continuously after it begins production of a product. Since a corporation does not secure additional cash until it sells or delivers its product, ${ }^{\circ}$ it must pay out of working capital those costs which must be met prior to sale.

The volume of costs which mature into expenses during the gap between production and sale is generally proportional to the length of the gap. The working capital needed for this gap may be computed by calculating the average daily production and operating expenses of a corporation, then multiplying by the number of days between production and sale. The corporate income statement generally classifies production and operating expenses as either cost of goods sold or selling, general, and administrative expenses [hereinafter $S, G$ \& $A$ expenses].

Cash requirements to meet the cost of goods sold can be computed separately and are treated below. Cash needed for $S, G \& A$ expenses is computed in accordance with the general method just described. First one determines the average length of time between commencement of production and sale, and expresses this time as a fraction of a year. Then one calculates the total $S, G$ \& $A$ expenses for the year, and subtracts depreciation, amortization, and other non-cash charges for which no working capital is necessary. The product of these figures yields the average working capital needed to finance $S, G$ \& $A$ expenses between production and sale.

9. The effect of the need for additional funds created by the sale of the goods on credit is discussed infra. For purposes of simplicity, transactions where the buyer prepays his order or makes "progress" payments at given stages of the work-as in a construction contract-are not discussed. The principles governing these transactions are essentially similar to other types of transactions except that there is either no interval or only a shortened period between production and sale. 
One major difficulty with the productive period method of computation is that it assumes that production time is constant. This assumption is generally valid only for businesses which manufacture or sell a single standardized product which is sold at an even pace throughout the year. A multi-product enterprise, however, may find it impractical to compute a production or resale period for each item. The simplest alternative is to group the products and determine a production or resale period for each category. This determination should be relatively routine for an accountant who must similarly calculate group depreciation and general cost allocation.

Where a corporation manufactures two or more products or product groups, average production time for each can be readily ascertained; but determining the average $S, G$ is $A$ expenses attributable to each involves some guesswork. Probably the best method is to allocate these expenses in proportion to the sales of each product. Of course, a product usually does not contribute the same percentage to sales that it does to total costs, but much of this disparity probably relates to the cost of goods sold. Proportional allocation of other costs is a standard accounting practice.

As the previous discussion has suggested, there is a certain degree of arbitrariness in calculating working capital needs. Thus, we have already assumed a corporation that can distinguish between specific and general overhead, that incurs, $S, G$ of $A$ expenses at a constant rate, and that can allocate these expenses among rationally defined groups of products. Obviously in each stage of the accounting process, a corporation has considerable latitude in deciding how to allocate its costs, and thus can substantially inflate working capital needs. But room for self-serving choice exists whenever there is any need to value property or compute income. In each case, a check is provided by well-recognized outer limits-"generally accepted accounting principles"-and by the often exacting demands of internal consistency. Confinement within these bounds is all that is necessary to insure that clear-cut avoidance schemes will not escape the accumulated earnings tax.

\section{Expenses Incurred During Production II: Cost of Goods Sold Expenses}

The cost of goods sold represents the direct costs of manufacturethe cost of raw materials and of labor and machinery employed in transforming the raw materials into finished products. Like $S, G \& A$ expenses, cost of goods sold expenses arise between commencement of production and sale. The determination of these expenses proceeds in 
an essentially similar manner. One deducts from annual costs of goods sold non-cash charges and multiplies the result by the production period expressed as a fraction of a year. ${ }^{10}$ Where there are two or more products, the cost of goods sold must be allocated among them. Ordinarily, labor and materials costs are far easier to allocate than $S, G$ if $A$ expenses and there will be no need to assume that these costs are proportional to sales.

\section{Expenses Arising From Extension of Credit: Accounts Receivable and the Collection Rate}

The first two needs for working capital dealt with expenses arising from the start of production to the point of sale. Accounts receivable needs arise because a corporation sells goods on credit, thereby increasing the time between commencement of production and receipt of funds. During this carrying period, the corporation must continue to finance current production without having available funds from recent sales. Adding a carrying period has the same effect on the corporation's working capital needs as lengthening the production period-as the period is extended, finance needs grow in proportion.

This relationship provides a method of calculating fund needs due to the extension of credit. One determines the average collection period for accounts receivable, and compares it with the production period. Needs arising from the extension of credit bear the same relationship to those arising from production $(S, G \& A$ expenses plus cost of goods sold) as the carrying period does to the production period. Thus, if production needs amount to $\$ 100,000$, the production period is ten days, the carrying period is thirty days, and the carrying needs come to $\$ 300,000$.

Determining the average collection period can be complicated. For

10. A second method of determining a corporation's need for cost of goods sold expenses first divides net sales by average inventory to secure the rate of turnover, which, when divided into 360 , is expressed in days. Cost of goods sold expenses will bear the same ratio to average inventory as the length of the production period bears to the length of the turnover period. Expressed differently, if a corporation knows in how many days fts inventory turns over, it knows that in that many days it will incur costs cqual to its average inventory. Accordingly, the amount of inventory used up as costs in the produc. tion period should equal the percentage that the length of this period is of the inventory period.

This second method for computing cost of goods sold expenses will be less accurate than the first. The turnover ratio assumes that the number of times inventory turns over during a year-which represents aggregate cost of salcs-is equal to total sales, whereis in fact these sales also must cover $S, G \& A$ expenses, other costs, and profit. Inventory actually turns less frequently than the ratio would suggest, although the disparity de. creases as cost of goods sold becomes a greater percentage of sales. 
the corporation as a whole, the average collection period is defined as the corporation's outstanding receivables divided by its annual credit sales.11 But where the corporation produces more than one product, it would be more accurate to calculate the carrying period for each product group rather than assume that each shares the average period. Unfortunately, corporations usually classify receivables by customer rather than product; and the overall figure may be the best available.

A second method of computing credit extension expenses is simpler but less accurate. It states that expenses are equal to average outstanding receivables. The theory of this method is that since receivables represent the sale price of products and since the sale price represents all costs of production, average receivables are equal to the costs of production that will arise between time of sale and receipt of payment, assuming that such production is constant throughout the year. The manifest weakness of this theory is that the sale price of products contains a mark-up for profit and an allowance for costs that do not become expenses before payment is received, so that average accounts receivable exceed actual expenses arising from extension of credit by the amount of this allowance.

\section{Allowance for Seasonal and Other Fluctuations}

A serious limitation on the computation of working capital needs under assumed "regular" conditions is that probably very few corporations sell goods at a uniform rate throughout the year. The corporation's plant is usually too small to meet peak demand on a current basis, and thus it must build up inventory in advance of the peak by producing in excess of current needs. As a result of this inventory buildup, production expenses are highest in the period before sales reach their peaks, while collection of accounts receivable does not generate cash until long after expenses have arisen (though usually in

11. Some corporations, however, may have no record of annual credit sales, although such cases probably are ferv. In these cases and in other cases where a corporation has records but a simpler calculation is necessary or desirable, computstion of the collection rate may use annual sales instead of annual credit sales. For many corporations in manufacturing and other non-retail busines the discrepancy between annual sales and annual credit sales is slight because substantially all of their sales are on credit. On the other hand for enterprises, notably retail establishments, whose cash sales constitute considerable part of total sales, accounts receivable is relatively less important, both as creator of a need for funds and as a source of supply of them as a component of working capital. This is true because a corporation's needs to meet expenses arising in the credit collection period is directly proportional to the percentage of total sales made on credit. From this it follows that as distortion in the collection period by use of annual sales instead of annual credit sales increases, the absolute amount of funds needed to meet expenses arising during the credit period decreases, thereby off-setting the impact of the distortion. 
time to meet expenses of the next pre-peak buildup). Since production and operating expenses arising during such a buildup will vary considerably from the average level, any measurement of adequacy of working capital which does not duly allow for these variations will be insufficient. $^{12}$

This means that the corporation must have cash on hand which, when added to collections of accounts receivable and cash sales for any period, will be sufficient to meet all expenses arising in the same period. If the pattern of expenses and receipts can be predicted in advance, ${ }^{13}$ the sufficiency of cash reserves can easily be calculated.14

12. To illustrate, a clothing manufacturer shows buyers his line of apparel for the coming fall in February or March. Based on the orders he receives the manufacturer will purchase cloth and produce most of his fall clothing line in late spring, although some production may continue into the summer. In July and August he will ship thic clothing he has manufactured to his customers for which he probably will receive pay. ment thirty to sixty days after delivery, or in early fall. At the same time as he is shipping his fall line of goods he will prepare his spring line for showing to buyers in September and early October, production at the end of the year and delivery in January and February. Because of his seasonal pattern of business the working capital needs of this clothing manufacturer fluctuate considerably. In late spring and at the end of the year his cash needs outstrip his income because the collection of his accounts receivable from the previous season's sales is complete except for slower-paying customers and because his volume of production, operating expenses, and inventory accumulation are far greater than his sales. In mid-summer and mid-winter this cash deficit narrows as he begins to deliver the coming season's apparel and reduce production of the current line of goods. By early fall or early spring, when production is at its ebb as he preparcs and shows the next season's line of goods, he has a strong cash surplus creatcd by peak collections of accounts receivable.

13. Of course, a corporation cannot always predict the pattern of its expenses and receipts. But the Internal Revenue Code makes special provision for this problem. If at the end of the year a corporation suddenly realizes it has made excessive accumulations it can still pay out these excess earnings and avoid liability for the tax. IRC \& 569(a) provides that dividends paid "on or before the 15th day of the third month following the close of ... [any] taxable year shall be considered as paid during such taxable ycar"; and under IRC $\$ 535$ (c) a corporation may deduct these dividends (as well as any amounts found accumulated to meet reasonable business needs) from the accumulated taxable income upon which the accumulated earnings tax is levied.

14. The vertical scale of the graph represents money, the horizontal scalc represents time. With one series of points a corporation plots its cash expenses for stated intervalls during a year; with a second series it plots its income from cash sales and collections of accounts receivable for the same period. Connection of the respective sets of points yiclds its yearly income and expense curves. The corporation then computes the amount that income exceeds or falls short of expenses for each given interval added to or sub. tracted from the previous excess or deficiency point, plots the result, and connccts the points to obtain its annual cash reserve curve. If, for example, income exceeds expenses by one unit at time one and four units at time two, the corporation plots points at onc unit at time one and five units at time two. The point at which the cash Icserve curve falls furthest below zero is the point at which aggregate expenses for the year most exceed aggregate income, and the amount this point falls below zero is the amount of cash reserves which a corporation must have at the beginning of the year in order to have cash adequate to meet seasonal fluctuations. In figure one the dotted line is the expense curve, the dashed line is the income curve, and the solid curve represents cash reserves. The corporation reaches its maximum cash reserve need point in early March when it will need $\$ 1,000,000$. Therefore this is the amount it needs to meet its scasonal fluctuations. 
The government may not easily be able to gauge the seasonal pattern of a business-but this will surely be possible for the business itself. Thus, the existence of any but the most obvious seasonal fluctuations, as a reason for working capital accumulation, should be a matter for affirmative proof by the taxpayer. ${ }^{15}$

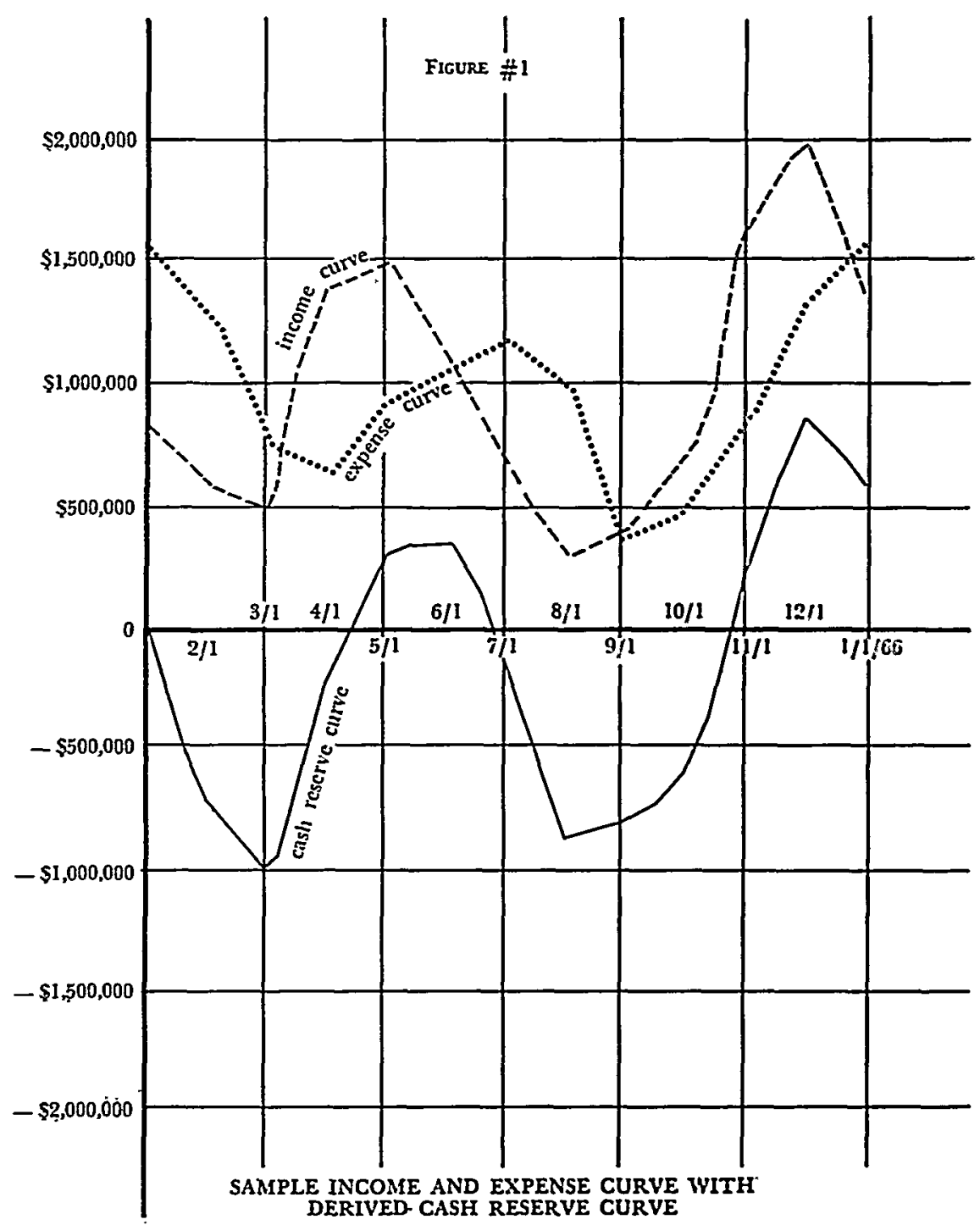

15. See IRC $\$ 534$ (c), permitting the taxpayer to submit facts in support of the grounds upon which it relies in defending the reasonableness of any accumulation of carnings and profits. 


\section{Debt Service}

The corporation must provide itself with funds to meet the maturing portion of its long-term debt; otherwise, the receiver would arrive before the tax collector. May it also claim that it needs to accumulate working capital to retire debt ahead of time? The Regulations consider actual prepayment of the debt to be reasonable. ${ }^{16}$ In another form of the problem the corporation could borrow large sums of money for use in its business, let earnings accumulate as a "reserve to prepay debt," but in fact retire debt only as due. The retention of earnings in this "reserve" would postpone payment of dividends until the reserve increased to an amount equal to unretired debt, after which time the corporation could accumulate no additional earnings for the purpose. Such an accumulation might be reasonable if the debt issue either had no sinking fund, had a "balloon"17 on the end, or could be prepaid only after a certain date. ${ }^{18}$ In each of these instances additional funds might be necessary to provide adequate cash reserve to retire the issue when due. Except for these three instances and the first situa. tion where funds actually are used to prepay debt, there seems to be no justification for retaining earnings to service future debt without raising arguments that the retention was a reasonably anticipated future need even if it was not a present one.

\section{Replacement of Capital}

In the course of its operations a corporation wears out and uses up its capital equipment, and must replace it in order to maintain its existing productive capacity. Capital replacement, therefore, is a working capital need, apart from any plans for expansion.

Depreciation charges do not measure this replacement need. Depreciation is a method of allocating wear and obsolescence of capital throughout its useful life. It is an accounting charge which begins upon acquisition, and ceases with sale or abandonment. Thus depreciation charges begin only after the cash outlay for equipment has been made. The charges themselves have no cash significance; they are neither a drain on working capital, nor a source of it. Instead, capital replace-

16. Treas. Regs. § 1.537-2(b)(3) (1965).

17. Where annual amortization of principal will not retire the debt by maturity, the outstanding balance at maturity is the "balloon." For example, a five-ycar loan of $\$ 1,000,000$, repayable in semi-annual installments of $\$ 75,000$, will amortize $\$ 675,000$ bcforc maturity, leaving a balloon of $\$ 325,000$.

18. For example, if the loan in the previous note could not be prepaid for the first two years, it would be of the type here mentioned. 
ment creates needs for working capital in the same manner as if it were an operating expense.

Sometimes expenses which are expected to provide services over many years, like research and development costs, are capitalized on the corporation's books. Nevertheless, these expenses, like capital purchases, are properly regarded as generating working capital needs.

These needs represent all the requirements for which a corporation may use working capital, although it may have other, further claims upon its assets. One such claim is current liabilities. Current liabilities arise because some of the costs incurred for any period of time will not have to be met until after the period ends. Current liabilities represent those costs accruing before a stated point of time (usually the end of a fiscal year) which become expenses subsequent to this point of time. Working capital, however, measures expenses not at a point in time but over a period of time. Since costs incurred in a given period but becoming expenses afterward will offset costs incurred prior to the period but becoming expenses within its duration, working capital need not take into account current liabilities. ${ }^{10}$

The working capital approach suggested in this comment will often require elaborate information and computations. Thus many courts and corporations may shy away from it and rely upon simpler arguments. In many cases the facts are sufficiently clearcut that extensive analysis is unnecessary. At no time, however, does any current or quick asset ratio provide a measure of reasonable working capital needs. At best these ratios are useful because any sharp deviation from some norm-whether prior years' ratios of the same company, ratios of other companies, or some arbitrarily chosen absolute-suggests inquiry into the cause of the deviation.

These criticisms apply with equal force to any rule that allows working capital in an amount equal to a year's operating expenses. As our entire discussion illustrates, any connection between aggregate operating expenses for a year and actual needs is coincidental.

Three recent cases have followed the "operating cycle" approach set forth in this comment. In the first of these, Bardahl Manufacturing Corp., ${ }^{20}$ the Tax Court defined the operating cycle to consist of the total

19. Of course, a business will have to accumulate cash in period 1 if liabilities incurred in that period but becoming due in period 2 exceed the liabilities incurred in period 2 which do not have to be met until period 3. Such accumulations, however, are probably" treated as reeting future rather than current needs; in the "operating cycle" approach current needs for period 2 take into account only the obligations arising from production in period 2.

20. 34 P-H TAX CT. REP. \& MEM. DEC. 1123 (1965). For an analysis of the differences in 
period of time required to convert cash into raw materials, raw materials into an inventory of marketable Bardahl products, the inventory into sales and accounts receivable, ... . to collect the outstanding accounts....21

In accordance with this definition the court computed reasonable working capital needs for each of the four years involved in the case by determining the average length of taxpayer's operating cycle over the four year period, expressing this cycle as a decimal fraction of a year, and multiplying the result by the sum of annual operating costs and cost of goods sold for each year. These needs plus non-working capital needs, when measured against net current assets plus non-current funds not employed in the business, determined the extent to which the taxpayer improperly accumulated earnings. ${ }^{22}$

The reasoning of the Bardahl case was adopted by the First Circuit in Apollo Industries, Inc. v. Commissioner. ${ }^{23}$ While accepting Bardahl's definition of an operating cycle, the court refused to hold the operating cycle approach applicable to all cases and used it only to test the "reasonableness" of the Tax Court's findings in the case on appeal. ${ }^{24}$ The court then advanced two other formulas: one to compute costs incurred during the collection period, which differs little from the computation of credit extension expenses discussed previously; the other to compute inventory costs, which, when analyzed algebraically, turns out to be no more than average inventory. ${ }^{25}$ The sum of these costs represented the total costs incurred during the operating cycle and hence were equal to working capital needs.

Both Apollo and Bardahl Manufacturing fail to recognize that a corporation's operating needs fluctuate during the year and from yearto-year, although the Apollo case did take into account some year-toyear changes. ${ }^{26} \mathrm{~A}$ considerably more sophisticated approach appears in Bardahl International Corp. ${ }^{27}$ This case involved a sister corporation

the formulas used in these two cases, see Horvitz, "Opening Cycle" Test, $24 \mathrm{~J}$. OF TAXATION 326, 328-29 (1966).

21. Id. at 1130 .

22. The table, id. at 1139, illustrates this approach.

23. 358 F.2d 867, 871 (1st Cir. 1966).

24. Id. at 872 .

25. There is an error in step $A 3$ of the computations for the year 1957 in footnote

26. Both cases also used a somewhat unrefined concept of an operating cycle, ignoring. for example, differences in the length of the operating cycle of different products manufactured by the same company. Since, however, both cases involved essentially oneproduct companies whose expenses for debt and capital replacement were insignificant, the employment of further refinements in these cases probably would produce complexitics not warranted by the additional accuracy they would yield.

27. 1966 P-H TAX CT. REP. \& MEM. DEC. I 66,182. 
(International) to Bardahl Manufacturing Co. (Manufacturing) which was the sole sales agency for Manufacturing and which purchased all of Manufacturing's output. Here, the court did attempt to consider the effect of fluctuations in business activity on working capital needs by recognizing that during certain months International's inventory turnover period and collection time for receivables was greater than in other months. Accordingly, to compute the length of International's operating cycle, the court chose the month when inventory turnover time and the collection period were at their peak and subtracted from the total length of the turnover and collection period for this month the average credit period extended by Manufacturing to International, apparently on the theory that purchases from Manufacturing made during the peak period were, to the extent of the average credit period, expenses that would not have to be met until after the peak period ended. Therefore, expenses of the period should be reduced pro tanto. 28

The principal difficulty with the court's attempt to consider fluctuating needs for working capital is that while International, because of Manufacturing's extension of credit, would not have to pay for some of its purchases from Manufacturing until after the peak period, nonetheless, during this period it would have to pay for prior credit purchases. The net effect would be that payment of the prior purchases would offset deferral of payment for the later purchases. Furthermore, the court's method of determining the period of greatest need was incorrect. The month when the turnover time and the collection period are greatest is the period of greatest need only if inventory turnover and collections proceed at a uniform rate throughout the year. The proper way to compute the period of greatest need has been indicated above.

Another major defect with the court's opinion, one that is also

28. Unaccountably, however, the court ceased to acknowledge that operating needs do fluctuate when it dealt with International's advertising expenses. Although it recognized that these expenses were greatest in February and XIarch, it said unt due allowance for them was made by their inclusion in total costs of an operating cjcle, presumably meaning that annual advertising expenses comprised part of total annual operating expenses which, when multiplied by the length of the operating cycle, yiclded the cost of that cycle. Id. at 1054. This assumes that advertising expenses occur at a constant rate. If the court had reached its conclusions because these expenses arose when other needs were not at their peak so that funds were available to meet them and because, when these other needs reached their peak, advertising expenses were at Icvels approximately equal to average annual expenses, then its conclusions would seem far more sensible. But as written, the court's opinion fails to explain why fluctuations in the level of operating expense should not receive the same consideration as fluctuations in other expenses. 
present in Apollo and Bardahl Manufacturing, is the use of net current assets as the measure of cash available to meet working capital needs. The net current asset method subtracts from the current assets available to meet expenses all current liabilities-i.e., past costs which must be met in the given period. It then subtracts from the expenses of the period all costs whose payment is deferred until a subsequent period. A much more convenient method is simply to use total current assets measured against total expenses arising in the cycle..$^{20}$

Despite defects in the opinion, Bardahl International is significant because the court not only tried to measure working capital needs in terms of an operating cycle, but also recognized that a cycle whose length is determined under an assumed constant rate of operation is not responsive to the realities of a corporation's working capital needs. Similarly, the court recognized that traditional rules of thumb (such as ratio tests or allowance of one year's operating expenses) failed to leave "room for consideration of many variables which may be applicable to the particular corporate situation."30 In short, the court's approach, which accepts the operating cycle method and manifests rare sophistication in applying it, gives much hope to those who seek a viable and realistic measure of a corporation's reasonable working capital needs.

$$
\text { NELSON J. LuRLA } \ddagger
$$

29. It should also be noted that the court did not use the net current assets method consistently. It subtracted from the expenses of the period some expenses deferred beyond it-e.g., federal taxes-but did not so subtract other deferred expenses.

30. Bardahl Int'I Corp., 1966 P-H TAX CT. REP. \& MEM. DEC. I 66,182, at 1061.

$\mp$ Associated with Ballard, Spahr, Andrews \& Ingersoll, Philadelphia. LL.B. 1966, Yale University. 